\title{
JURISTS AND THE LAW IN THE EARLY ROMAN EMPIRE By MICHAEL PEACHIN
}

I would like to begin this paper with three quotations from Bruce Frier's stimulating book, The Rise of the Roman Jurists (Princeton 1985):

"Late Republican sources paint a discouraging picture of indefiniteness and insecurity in the judicial system of Rome: the procedural forms of the Edict shifted constantly; rhetorical advocacy remained supreme in harsh adversary trials; broad social commitment to minimum standards of formal justice was still lacking; public ignorance of law was widespread; the judicial system was still passive; and, at the margin of this pandemonium, a handful of jurists struggled to establish a place for their tenuous legal science." (p. 183)

"Legal insecurity, the uncertainty surrounding legal norms and their application, was beyond any doubt the most pervasive feature of the Ciceronian court." (p. 249)

\begin{abstract}
"Law was finally sundered from the elaborate apparatus of case-oriented rhetorical argument and was made over into an abstract body of norms, on the basis of which legal claims could in principle be scrutinized without special reference to the person of the claimant; gradually the participants in the Roman judicial system were persuaded to understand and use the law in this way." (pp. 286-7)
\end{abstract}

So, as Frier indicated in closing his book, and as most students of the law would, I guess, be inclined to argue, the Classical period of Roman law did much to remove the sorts of legal insecurity that had plagued the earlier Republican period. Under the Empire, jurisprudents took over, created an abstract body of norms, and these could then (in principle) be applied with something like regularity in the courts. ${ }^{1}$ Now, while I would not want to deny

\footnotetext{
${ }^{1}$ For the argument (very briefly) that jurisprudence was the most important source of law during the early Empire, see G. Negri, 'Giudici e «responsa prudentium»', in F. Milazzo (ed.), Gli ordinamenti
} 
entirely that things went this way -- and here, let me stress from the outset that the simple vastness of the body of juristic literature created during the early Empire represents by itself a huge improvement over what had gone before --, still I think that most of the problems identified by Frier in the Republican system continued, in varying degrees, under the Empire. Moreover, the arrival of a monarchic (let me even dare to say autocratic) system of government could perhaps even be argued to have added roadblocks on the path to a legal system potentially based on something like what we would call regularized formal justice.

In what follows, then, I want first to argue, just briefly, that the problems in the Republican system noted by Frier were, to a large degree, not corrected under the imperial regime. Secondly, by way of considering the actual role played by early imperial jurists in creating the law, I want to present the evidence we have for legal discussions that took place in the emperor's consilium. For here, we can observe the princeps interacting with legal experts, and then rendering real decisions in real-world cases. There will not be time to analyze this material properly, but by setting it before us, some sense of the power of the jurists over the everyday life of the law will emerge.

First, then, let us run through the points raised by Frier, and try to assess just briefly the imperial situation with regard to these matters.

The constant shifting of the praetor's edict was brought to a halt during the waning years of Hadrian's reign, when Salvius Julianus created an edictum perpetuum. Until this moment, though, praetors can perhaps still have made changes to the edict, just as they did in Republican times. ${ }^{2}$ Moreover, Julianus' codification may not ultimately have made things much simpler; for this effort gave rise to a subsequent huge literature of commentaries on the (now codified) edict. Ulpian, for example, wrote 81

giudiziari di Roma imperiale. Princeps e procedure dalle leggi giulie ad Adriano. Atti del convegno internazionale di diritto romano e del III Premio romanistico "G. Boulvert». Copanello 5-8 giugno 1996 (Naples 1999), $409 \mathrm{ff}$.

${ }^{2}$ On this point, see N. Palazzolo, 'Il princeps, i giuristi, l'editto. Mutamento istituzionale e strumenti di trasformazione del diritto privato da Augusto ad Adriano', in F. Milazzo (ed.), Res publica e princeps. Vicende politiche, mutamenti istituzionali e ordinamento giuridico d Cesare ad Adriano. Atti cel Convegno internazionale di diritto romano Copanello 25-27 maggio 1994 (Naples 1996), $310 \mathrm{ff}$. It must be admitted, however, that others suppose the edict already in the first century to have become static (see Palazzolo for bibliography). 
books of comments, and Paul contributed 80. Nor were they alone in this enterprise. $^{3}$ Thus, it seems to me that even the official stabilization of the edict itself must not really have stopped the perplexing process of shifting that had characterized this material during the Republic.

As for rhetorical advocacy, Tacitus produces a claim, in his Dialogus (39), that by the late first century it was effectively defunct: judges would now supposedly force advocates to stick to the (legal) point, and there were no longer boisterous crowds attending court cases. This, however, seems hardly to reflect the real world. Quintilian, in his Institutiones Oratoriae, appears generally to presume the presence of a substantial courtroom audience. Turning to the world of actual trials, Pliny (Epistulae 7.6.9), for example, talks of the ingens coetus present at a trial for poisoning, where he was advocate for the defendant. And as to how the arguments were conducted, in referring to his arch-rival in the courtroom, M. Aquilius Regulus, Pliny (Epistulae 1.5.15) says that the man was "difficult to knock down" (dyskathaireton), and he complains generally in this letter (providing, in fact, examples) about Regulus' antagonistic, even abusive rhetorical style. ${ }^{4}$ Without presenting more evidence, let me just say that it would seem rash to accept the report of Tacitus, and to assume that either the rhetorical advocacy or the harsh adversarial trials of Republican days was banished from the courts of the Empire.

As regards anything like a "broad social commitment to minimum standards of formal justice," I can see no way of gauging this absolutely. Nevertheless, I think that one can present a strong circumstantial argument against there having been any such commitment during the early imperial period. In any case, I have attempted to make that argument in a fairly recent book, and will here simply refer to that. ${ }^{5}$

Part of my argument in that same book, moreover, was that the widespread public ignorance of the law, which Frier notes for the Republic, was for a variety of reasons not rectified by the imperial regime. The sources of law continued to be problematic in various ways. And while there was

\footnotetext{
${ }^{3}$ There were imperial-age commentaries, aside from Ulpian's and Paul's, by: Vivianus, Massurius Sabinus, Sextus Pomponius, Sextus Pedius, Furius Anthianus, Callistratus, and Gaius. And in fact, there were already in Republican times commentaries written on the praetor's edict: Servius Sulpicius Rufus, Aulus Ofilius, and M. Antistius Labeo.

${ }^{4}$ Both Pliny and Martial talk of Regulus' impressive abilities as orator. Cf. PIR ${ }^{2}$ A 1005 for testimonia.

${ }^{5}$ M. Peachin, Iudex vice Caesaris. Deputy Emperors and the Administration of Justice during the Principate (Stuttgart 1996), 10-91 and also 204-207
} 
certainly more written on the law, these writings were in no way codified, or made easily or widely available to the public (or, for that matter, to governmental officials, or to advocates). In short, I think we must reckon with a large degree of legal ignorance throughout the early imperial period too. ${ }^{6}$

Nor does it seem easy to point to evidence that would indicate the imperial regime casting off the passivity of the Republican legal order. And where legal insecurity (i.e., "uncertainty surrounding the legal norms and their application") is concerned, here too I have argued at length for a concatenation of factors that resulted in a great deal of such trouble during the Empire (above, n. 5).

In short, the jurists did go about creating a very large, and a very impressive, "abstract body of norms" during the first two or so centuries of the Empire. These experts were no longer quite so few, and they now arguably stood not so much at the margins, but rather, closer to the center of the pandemonium. We furthermore have evidence to show that some people, sometimes, in some places, knew at least something of the jurists' legal opinions -- and even that they tried to put these to use in real-world courtrooms. ${ }^{7}$ Let me not, therefore, give the impression of being utterly pessimistic regarding this whole business. Indeed, there was some progress. However, I think that it would be seriously misleading to presume that the jurists, and the law as they expounded it, came absolutely to rule courts of law during (say) the first two or so centuries A.D. Furthermore, there was one factor present during this period, which was not at all around under the Republic, and which might, on occasion, play havoc with law as prescribed by the jurists. I refer to the person of the princeps. ${ }^{8}$

\footnotetext{
${ }^{6}$ Peachin 1996, op.cit. (n. 5), 33-65.

${ }^{7}$ For example: CJ (= Codex Justinianus ) 3.42 .5 (12 February 239), where Gordian informs a soldier named Sabinianus that the responsum of Modestinus is valid; Fragmenta Vaticana $44=$ FIRA $^{2}$ II p. 473, where Ulpian responds to someone called Aurelius Felix; CJ 5.71.14 (14 November 293), where Diocletian and Maximian tell Frontinus that he may use responsa (these, by now, obviously recorded in written form) of Papinian and other jurists in court.

${ }^{8}$ For the sake of brevity, I have left out of the present discussion entirely the question of complications that may have arisen once the so-called cognitio extra ordinem of the Principate began to function side-by-side with the old formulary procedure. A full discussion would have to raise this matter too. In this regard, cf. Palazzolo 1996, op.cit. (n. 2), $314 \mathrm{ff}$.
} 
Now, it is clear that an emperor could, if he wanted, disregard anything and everything that had ever been said, or written, about the law by any jurist - that he could, in fact, do as he liked in the legal realm. ${ }^{9}$ We hear precisely this from the Severans, saying that they, although freed from the laws, would agree nonetheless to abide by them..$^{10}$ With this in mind, let us, then, turn to a specific body of evidence, namely, a group of reports contained in the Digest of legal discussions held in the imperial consilium. Fergus Millar some time ago wrote that the role of the jurists, as it emerges from these texts, is "purely advisory." "That is surely right; but it is perhaps worth looking at the passages together, and a bit more closely. ${ }^{12}$

1. Dig. 4.4.38 pr. (Paul, 1 decretorum). [Septimius Severus] Aemilius Laurianus buys a fundus, and agrees to complete payment for the property within two months of the sale. He dies, however, before all payments are made. The tutors of his daughter, who inherits the property from him, do not make payments, and are warned to do so by the seller. When they consistently neglect this duty, the seller takes back the property. The daughter then seeks restitutio in integrum, first before the praetor, and then in the urban prefect's court. She loses both times, and has now appealed to the emperor. Paul and the emperor disagree about the matter (all the details need not be presented here), with Paul supporting the earlier decisions. In the end, because he was displeased by the clause allowing revocation of the contract (quia tamen lex commissoria displicebat ei), the emperor overruled all of Paul's arguments, and granted the restitutio. It is worth noting that there was, from all appearances, nothing strictly illegal about the lex commissoria.

2. Dig. 14.5.8 (Paul, 1 decretorum). [Septimius Severus] Titianus Primus appointed a slave to do particular kinds of business; but the slave

\footnotetext{
${ }^{9}$ For one example, where the emperor simply overrules that which "the jurists" think (interpretentur), see CJ 9.23.1 (6 September 212).

${ }^{10}$ Justinian, Institutiones 2.17.8. Cf. also CJ 6.23.3 (22 December 232).

${ }^{11}$ F. Millar, The Emperor in the Roman World (Ithaca \& London 1977, 2nd ed. 1992), 238.

${ }^{12}$ After the textual citation for each case, I give in brackets the emperor in question. Several of the texts listed below derive from one of Paul's two books of imperial constitutions: Imperialium sententiarum in cognitionibus prolatarum libri VI or the Decretorum libri III. There are problems as to the date of composition of these two books, and thus also questions as to what emperor is in question in any given text. While it may be that both Septimius Severus and Caracalla come in question, it is perhaps better to assume that these books hold mainly decisions just of the former. See now D. Liebs in R. Herzog and P.L. Schmidt (eds.), Handbuch der lateinischen Literatur der Antike Bd. 4 (Munich 1997), 172. I have argued elsewhere that at least two texts from these books (Dig. 10.2.41 and 37.14.24) record a case tried before Caracalla: M. Peachin, 'The Case of the Heiress Camilia Pia' Harvard Studies in Classical Philology 96 (1994), $301 \mathrm{ff}$.
} 
went beyond these, also taking up and paying off debts owed to grain dealers. Then, the slave fled, leaving a debt unpaid, and the creditor sued Primus. In the trial, it came out that the slave had been conducting yet other types of business dealings; hence, the now suspicious praefectus annonae (the initial judge) ruled against Primus, upon which there was an appeal to the emperor. Paul says "I/we argued" (dicebamus) that the master was not liable (several reasons are given for the argument). However, the emperor agreed with the praefectus annonae, thinking that the slave seemed to have been working generally as a substitute for his master.

3. Dig. 28.4.3 (Marcellus, 29 digestorum). [Marcus Aurelius] In a cognitio before the emperor, the problem arose of a testator (Valerius Nepos), who had erased the names of the instituted heirs, but not of the legatees. Because of the erasure of the heirs' names, the man's property was being claimed by the fisc. ${ }^{13}$ There was then a long discussion of the legacies (diu de legatis dubitatum est). Marcellus favored a more lenient approach, namely, allowing these to stand, and arguing that Nepos had intended to invalidate only that which he had erased. Most of the members of the consilium (plerique) thought that erasure of the instituted heirs made the entire will invalid. In the end, after some private consideration, the emperor also decided in favor of allowing the legacies (i.e., in accord with Marcellus, but against the majority opinion). The decision, n.b., was based on a presumption by the emperor of what the testator's intentions (voluntas) had been.

4. Dig. 29.2.97 (Paul, 3 decretorum). [Septimius Severus] Clodius Clodianus instituted the same man in two different wills, the second improperly executed. The heir wanted to take under the second will, but then found that it was invalid (because of the improper execution). Papinian held that the heir had (presumably by implication) refused to take under the first, and could not do so under the terms of the second (since it was invalid). Paul argued that there was no refusal to accept the first will, since the heir assumed the second will to be valid. The emperor decided that Clodianus had died intestate.

5. Dig. 32.27 pr. - 1 (Paul, 2 decretorum). [Septimius Severus] Pompeius Hermippus leaves his son, Hermippus, heir to $3 / 4$ of his estate, while his daughter, Titiana, was left $1 / 4$. He also gave to each specific praedia in advance of his demise. Furthermore, the will stated that if the son

\footnotetext{
${ }^{13}$ The advocatus fisci, Calpurnius Longinus, is here quoted specifically, arguing that no will without an instituted heir can be valid.
} 
were to die first, then the daughter was to inherit yet another piece of property. Pompeius Hermippus wrote a codicil, emending the will. He had given Titiana already by this time further properties still, and he said in the codicil that she should be satisfied with these in place of the entire inheritance left her by the will. The father died, and for reasons unknown, the son's property became forfeit to the fisc. At that point, Titiana went against the fisc, asking for restoration of the property which, according to the terms of the father's will, was to go to her upon the son's death. In this instance, Paul pleads for a more severe line, following strictly the wishes of the testator; but the emperor takes a more humane stance (placuit [sc, imperatori] humanius interpretari), n.b., here again, against the interests of the fisc.

6. Dig. 35.1 .48 (Marcellus, 15 digestorum). [Marcus Aurelius] A trust had been left to someone "when he reached his sixteenth year" (cum ad annum sextum decimum pervenisset). Marcellus argued that this trust did not become due at the moment when the person entered into that year of his life (cum...ingressus fuisset). The emperor agreed with this interpretation. N.b., the case was an appeal from Germany (from the court of the governor?).

7. Dig. 37,12,5 (Papinian, 11 quaestionum). [Trajan] A father was mistreating his son; thus, Trajan forced emancipation of the son. Soon after, the son died, and the father claimed the son's property. Neratius Priscus and Titius Aristo convinced Trajan not to allow this, because the father had neglected his duty to the son.

8. Dig. 37,14,17 (Ulpian, 11 ad legem Iuliam et Papiam). [Marcus Aurelius] A problem that confronted Marcus and Verus is described. Could bonorum possessio contra tabulas, with respect to the property of a grandfather's freedman, be granted to the grandson if the father (of the grandson) had brought a capital charge against the freedman? Relying on Proculus' opinion, the emperors had replied negatively to Caesidia Longina. At the moment of the reply, Volusius Maecianus had gone along with the negative opinion, seemingly out of respect for the emperors. But then came further discussion with Maecianus and other legal experts, after which the opposite opinion seemed better. Moreover, Salvius Julianus agreed with the second decision.

9. Dig. 49.14.50 (Paul, 3 decretorum). [Septimius Severus] An imperial procurator, Valerius Patruinus, assigned certain praedia to Flavius Stalticius for a fixed price. There was a subsequent auction of the property, and Stalticius again got it. But what of the products of the property in the 
interim? Patruinus wanted these to go to the fisc. Since both assignations had been made during the time of the harvest, it was generally agreed that the products should belong to Stalticius. Papinian and Messius argued that since the property was in the hands of a tenant, he ought to get some of the produce, while the buyer (Stalticius) would receive rent (from the tenant). The emperor agreed with this: if the tenant were cultivating, then he would gather the produce, and Stalticius would receive rent, whereas if Stalticius were cultivating, then he would take the produce. Tryphoninus then asked about dried fruit on the estates, which had been gathered previously. The emperor says that if the day for payment of rent had not yet come when the property was assigned, then it would go to the buyer.

10. Dig. 50.16.240 (Paul, 1 imperialium sententiarum in cognitionibus prolatarum). [Septimius Severus] When by contract "the dowry must be returned upon dissolution of the marriage", does this mean just upon divorce, or does it also hold upon death of one party? Many (in the consilium) said yes, just upon divorce; some others thought not. The emperor decided that under no circumstances could the husband keep the dowry.

So, we have only ten of these discussions -- in other words, a terribly meagre sample. Moreover, six of the ten record decisions by (presumably) Septimius Severus, with one by Trajan, and three by Marcus Aurelius. Thus, whatever we say on the basis of this evidence must remain tentative at best. Nevertheless, certain things do seem to emerge.

First, it seems clear, just as Millar claimed over twenty years ago, that, generally speaking, the emperor made the decisions. Still, an intriguing pattern emerges here. In all four second-century texts $(3,6,7,8)$, the emperor is clearly persuaded to decide as he does by the arguments of the jurists on his consilium. In four other cases $(1,2,4,5)$, the princeps (presumably Severus) makes a decision pretty well utterly independent of what the jurists have argued. And in the two last cases $(9,10)$, the emperor (again, Severus) hears the jurists, is influenced by them, but nonetheless makes a fairly unilateral decision. Thus, if this evidence is at all probative of anything, it would appear that the third-century Antonines were much more likely than their second-century namesakes to listen to their legal advisors, but then to take a line that they simply preferred. Whether we are here in the presence of a large-scale historical development, or simply the idiosyncrasies of one or both of the first two Severans, cannot be determined with any certainty. But there might indeed be a change reflected here. 
A related question arises. Do these largely independent decisions of Severus work in accord with the law, i.e., the law as conceived by the jurists, or are they idiosyncratic? A proper discussion of this needs to be much more extended, needs to consider the legal problems involved more carefully; however, I think that the following can be said with rough safety. Let us consider the four cases where an emperor decides, so to speak, alone (nos. 1, $2,4,5$ ). In the first, two judges (the praetor and then the urban prefect) have ruled against Aemilius Laurianus' daughter. The jurist Paul, in discussion in the consilium, agreed with these judgements. However, the emperor decides to void a perfectly legal clause in a contract for sale, "because it displeased him," and thereby grants the daughter her restitutio. ${ }^{14}$ In the second case, a slave had been conducting various kinds of business, though without any demonstrable authorization from his master, Titianus Primus. When Primus was sued over one of the transactions entered upon by his slave, the praefectus annonae had suspected complicity, and had ruled against Primus. An appeal brought the matter to the emperor's tribunal, where Paul argued, among other things, that there was nothing to prove that the slave had been working with Primus' authorization. Despite, then, the lack of a solidly legal basis for such a decision, the emperor, who was simply suspicious, like the prefect of the corn supply, ruled against Primus. ${ }^{15}$ In the third case, that of Clodius Clodianus and his two wills, both Papinian and Paul offered solutions to the problem at hand, though they differed on the ultimate result, with the former denying the inheritance, the latter allowing it. The emperor, however, effectively renders a non liquet, but simply proclaiming that Clodianus died intestate. ${ }^{16}$ The details of the fourth case need not be repeated (see above); and it is perhaps easiest simply to quote Dieter Nörr on the ultimate decision here: ${ }^{17}$ "An dieser Stelle wird es deutlich, da $\beta$ Jurist und Kaisergericht auf verschiedenen Ebenen argumentieren, die 'kritisch' kaum vergleichbar sind. Paulus argumentiert juristisch; der Kaiser fällt eine Art 'Gnadenentscheidung', die zulasten des Fiskus geht. Man könnte daran

\footnotetext{
${ }^{14}$ For further discussion of this case, see D. Nörr, Rechtskritik in der römischen Antike (Munich 1974), 128 and T. Honoré, Emperors and Lawyers (Oxford 1994, 2nd ed.), $23 \mathrm{f}$.

${ }^{15}$ Nörr 1974, op.cit. (n. 4), 129 says of the decision here: "Wahrscheinlich wird man auch hier den Gegensatz zwischen der zugleich konservativen wie auch dogmatischen Haltung des Juristen und der freieren Gestaltung durch die Beamtenkognition und das Kaiserrecht erkennen können.”

${ }^{16}$ Nörr 1974, op.cit. (n. 4), 127-128 argues that the emperor has decided, in effect, according to Papinian's opinion.

${ }^{17}$ Nörr 1974, op.cit. (n. 4), 130.
} 
zweifeln, ob Paulus als 'Richter' eine solche Entscheidung überhaupt hätte fällen dürfen."

There is something common to all these cases. In all of them, the emperor decides against the opinion held by one or more of the jurists advising him. Moreover, to one degree or another, in doing this, the prince also rules against the strict letter of the law. In short, he confounds formal justice. His judgements may seem (or have seemed) somehow fair, or just, but they do not necessarily abide by the law as it was produced, or expounded, by legal experts.

Initially, then, I tried above to illustrate any number of factors that will have worked, during the period from (say) the death of Augustus down to the reign of (say) Severus Alexander, to undermine the power wielded by jurisprudents over the course that real trials in the real world might take. This material was augmented by close examination of several actual legal cases heard in the imperial consilium. There too, the power of the jurists was seemingly limited. Having presented this evidence, it is nonetheless important to stress that it would be unwise to take the resultant line of argument too far, and thus to suppose that jurists had no power whatsoever over adjudicative situations. The reality is perhaps best put this way. At tribunals the empire over, or at the court of the emperor, jurists and their opinions might carry the day; but they might not. Nor was there a systematized mechanism for determining when the law would rule, as opposed to when it would not. Rather, the judge, whether emperor, provincial governor, praefectus urbi, procurator, or some other, could (and did) make that decision on an ad hoc basis. ${ }^{18}$ Given, then, this situation, we should ask ourselves, I think, some questions about the position of jurists vis à vis the law, and in particular, questions regarding the jurists' own conceptions of the project in which they were engaged.

In concluding, I would like to pose one rather large question; and I want to answer it in a preliminary, and, admittedly, a provocatively perfunctory way. Let me formulate the conundrum precisely. Given the above-portrayed constraints on the efficacy, in actual trial situations, of that said or written by early imperial jurists, what precisely did these men have in

${ }^{18}$ Cf. in this regard Nörr 1974, op.cit. (n. 4), 130 ff. for some ancient criticism of procuratorial jurisdiction. 
mind when they sat down to compose legal tractates? That is to say, did the jurists think, or hope, that they would somehow break through such barriers, and somehow gain control over the doings in court? Or was some modified version of "making (or controlling) the law" on their minds as they wrote? And taking the inquiry a small step further, can there even have been concerns other than simple exposition of the law driving them?

Again, it seems to me highly unlikely that the typical Roman jurist thought in terms compatible with anything we would happily recognize as formal justice. In other words, given the mechanisms working against the rule of law, it seems difficult to imagine that a man like Ulpian supposed his opinions would (as opposed to could) bind and regulate Roman society as a whole. ${ }^{19}$ But even aside from that, it has become more and more clear in recent years that the law, as produced by jurisprudents, concerned itself really with a small group of people. Jurists' law was designed mainly with the elite in mind -- and let us not forget, the jurists themselves were members of that same elite. This law could be, and often was, applied to, or used by, those lower down the social ladder; but, it was not created with them in mind; and it was not (I think) necessarily produced in order to guarantee that their affairs were well regulated. Beyond this, even where the elite itself was concerned, juristic law could be limited. For example, as Frier has demonstrated, the law of rent, such as it exists in the law codes, was focused on one particular upper-class rental market, namely, that at Rome. ${ }^{20}$ The jurists who wrote this law must have assumed that those living elsewhere would either adapt their dealings to what had been produced with Rome in mind, or, alternatively, would simply adhere to their local customs or laws.

In sum, when a Roman sat down to write a treatise on the law, he appears most usually to have been focusing principally on a small, elite group; moreover, a group which itself could not absolutely expect that the

\footnotetext{
${ }^{19}$ Let me simply reproduce here a standard definition of formal justice. J. Rawls, $A$ Theory of Justice (Cambridge, Mass. 1971), 58: "Now let us suppose a certain basic structure to exist. Its rules satisfy a certain conception of justice. We may not ourselves accept its principles; we may even find them odious and unjust. But they are principles of justice in the sense that for this system they assume the role of justice: they provide an assignment of fundamental rights and duties and they determine the division of advantages from social cooperation. Let us also imagine that this conception of justice is by and large accepted in the society and that institutions are impartially and consistently administered by judges and other officials. That is, similar cases are treated similarly, the relevant similarities and differences being those identified by the existing norms. The correct rule as defined by institutions is regularly adhered to and properly interpreted by the authorities. This impartial and consistent administration of laws and institutions, whatever their substantive principles, we may call formal justice."

${ }^{20}$ B. Frier, Landlords and Tenants in Imperial Rome (Princeton 1980).
} 
regulations thus formulated would always govern its affairs. Thus, when (say) Ulpian wrote, he must have been aware of these (in our terms) limitations on what he was doing. And given that, he will not, I think, have presumed himself simply and purely to be "making the law" for the Roman world -- in spite of the fact that we now read and employ this literature as if that had been the case.

What, then, was our Ulpian up to? Perhaps we should try to conceive his project more in the following vein. One of the things that a proper Roman aristocrat did, ideally, was to write. And when such a man sat down to write, he habitually chose from a relatively limited field of possible topics. If he did not select poetry, of one kind or another, history, epistolography, biography, or possibly panegyric, then he was highly likely to opt for one of the genres included in Cornelius Celsus' encyclopedic Artes: farming, medicine, military science, rhetoric, philosophy, or law. ${ }^{21}$ Given this, might it then just be possible that what an Ulpian most centrally thought himself to be engaging in was writing, and that the actual subject matter chosen was, in a sense, or to a degree, secondary? Was he, perhaps, creating first and foremost a personal monumentum, as did (say) Pliny with his letters, but now with jurisprudence as the medium? If there is any merit at all to this suggestion, then the precise relationship of the law, as it was actually practiced, to the men who expounded it will require some rethinking.

Gregory Thaumaturgus, writing in the mid-third century A.D., claimed that law was (still in his day) created by the jurisprudents; and constitutions like those mentioned above (n. 7) lend this assertion veracity. ${ }^{22}$ However, if we read such a passage, and then think in terms of "making the law" in our own societies, we may perhaps be doing a certain injustice to the project as conceived by the Roman iurisprudentes themselves.

New York, November 2000

${ }^{21}$ On this work, as a whole, see still M. Schanz and C. Hosius (eds.), Geschichte der römischen Literatur bis zum Gesetzgebungswerk des Kaisers Justinian. Zweiter Teil. Die römische Literatur in der Zeit der Monarchie bis auf Hadrian ${ }^{4}$ (Munich 1935), 722-725. Note that there is some question as to whether sections on law and philosophy were originally included.

${ }^{22}$ In Originem I (Pat. Gr. 10.1052-53). 